\title{
PUBLIC HEALTH HAZARDS ASSOCIATED WITH NATURALLY OCCURRING TOXINS IN LEGUME SEEDS - RAPID DETECTION AND CHARACTERIZATION OF A LECTIN FROM A KOREAN CULTIVATED KIDNEY BEAN (PHASEOLUS VULGARIS L.)
}

\author{
NADER NCIRI ${ }^{1,2,3 *}$, TAESUB SHIN ${ }^{3}$, NAMJUN CHO $^{3}$ \\ ${ }^{1}$ Intestinal Immunophysiology-Research Unit (02/RU/09-02), Faculty of Medicine of Tunis, University of Tunis El Manar, Bab Saâdoun, \\ Tunis, Tunisia. ${ }^{2}$ Department of Animal Resources, Fisheries, and Food Technology, National Institute of Agronomy of Tunisia, El \\ Mahrajène, Tunis, Tunisia. ${ }^{3}$ School of Energy, Materials, and Chemical Engineering, Korea University of Technology and Education, \\ Cheonan, Chungnam, Republic of Korea. Email: nader.nciri@yahoo.fr; nader.nciri@koreatech.ac.kr
}

Received: 20 November 2017, Revised and Accepted: 20 December 2017

\section{ABSTRACT}

Objective: The delicacy of kidney beans is highly appreciable but, at the same time, their toxicity has raised an alarming concern. In this regard, more public awareness is needed about bean poisoning.

Methods: This work aimed at promptly investigating the chemical and biological properties of a lectin derived from a Korean cultivar of the common bean (Phaseolus vulgaris L.).

Results: Sodium dodecyl sulfate-polyacrylamide gel electrophoresis revealed the presence of two major polypeptide bands around $31.00 \mathrm{kDa}$. Hemagglutination assay and Ouchterlony double immunodiffusion technique confirmed the presence of lectin in dry seeds.

Conclusion: It was evident that the Korean bean cultivar contains biologically active lectins, which may pose a risk to the consumer if the beans are eaten in raw or undercooked state.

Keywords: Common bean (Phaseolus vulgaris L.), Hemagglutination assay, Korean cultivar, Lectin, Ouchterlony double immunodiffusion, Phytohemagglutinin, Sodium dodecyl sulfate-polyacrylamide gel electrophoresis, White kidney bean (Phaseolus vulgaris L.).

(c) 2018 The Authors. Published by Innovare Academic Sciences Pvt Ltd. This is an open access article under the CC BY license (http://creativecommons. org/licenses/by/4. 0/) DOI: http://dx.doi.org/10.22159/ajpcr.2018.v11s3.30037

\section{INTRODUCTION}

Raw kidney beans (Phaseolus vulgaris L.) are one of the most important legumes of nutritional interest in South Korea. In many countries, they are harvested to obtain a relatively inexpensive and good protein supply both for animals and humans [1]. However, they contain several antinutritional components that can limit their consumption. The main antinutritional factors occurring in these beans are tannins, phytates, protease inhibitors, and lectins (known as phytohemagglutinins [PHAs]] [2-4]. Thus, the ingestion of raw or inadequately-cooked beans may give rise to a certain number of undesirable physiological and biochemical effects [5-7]. These effects are basically reflected by failure of growth and weight loss in animals and gastrointestinal symptoms (i.e. nausea, vomiting, and diarrhea) in man [8]. It is generally believed that the lectins in $P$. vulgaris are the main causative agent responsible of these deleterious effects $[9,10]$. In this regard, some special attention should be given to the possible occurrence of bioactive lectins in human diets. More particularly, it cannot exclude that some lectins present in crop plants could escape detection. In addition, the presence of low levels of a toxic lectin can be masked by the occurrence of high concentrations of a harmless lectin. The present paper describes the partial extraction of a lectin derived from a Korean cultivar of the common bean $(P$. vulgaris $\mathrm{L}$.) and the determination of some of its chemical and biological properties; as a first step in the attempt to understand its role in the plant and its contribution to the poor nutritive value of the legume.

\section{METHODS}

Seeds and preparation of crude bean extract

Samples of a Korean cultivar of the common bean (P. vulgaris L., Fig. 1a) were purchased from a local supermarket in Cheonan City,
Chungnam Province, South Korea. For the preparation of extract for hemagglutination and immunodiffusion tests, $50 \mathrm{~g}$ of seeds were ground to a fine powder $(<75 \mu \mathrm{m}$, Fig. $1 \mathrm{~b})$ in a prechilled mortar and pestle. To approximately $300 \mathrm{mg}$ of this powder, $3 \mathrm{~mL}$ of chilled extraction buffer (tris- $\mathrm{NaCl} ; 50 \mathrm{mM}$ tris- $\mathrm{HCl}$ and $50 \mathrm{mM} \mathrm{NaCl}$, at $\mathrm{pH} 7.6$ and $4^{\circ} \mathrm{C}$ ) was added. The mixture was homogenized until a uniform slurry was obtained and then centrifuged at $3500 \mathrm{rpm}$ for $30 \mathrm{~min}$ at $4^{\circ} \mathrm{C}$. The supernatant was dialyzed overnight at $4^{\circ} \mathrm{C}$ against the tris- $\mathrm{NaCl}$ buffer ( $\mathrm{pH}$ 7.6). The dialyzed extract was used for hemagglutination and immunodiffusion tests without further purification.

\section{Hemagglutination assay (HA)}

HA was performed in a 96-well microtiter U-plate (Greiner Bio-One, Monroe, North California, USA). Starting with $50 \mu \mathrm{L}$ of the crude bean extract, serial 2-fold dilutions (i.e. $1 / 1,1 / 2,1 / 4,1 / 8,1 / 16,1 / 32,1 / 64$, $1 / 128,1 / 256,1 / 512,1 / 1024$, and $1 / 2048$ ) were made with $0.9 \%$ physiological saline (phosphate-buffered saline [PBS], pH 6.8). Then, $2 \%$ human red blood cell type A ( $50 \mu \mathrm{L}$; supplied by Dr. Nader Nciri from the Department of Energy, Materials, and Chemical Engineering, Korea University of Technology and Education) suspension was added. The plates were covered to prevent moisture evaporation and gently shaken on platform shaker for $10 \mathrm{~min}$. After $1 \mathrm{~h}$ incubation at $37^{\circ} \mathrm{C}$, agglutination patterns were observed visually and with the aid of microscope (Leica Microsystems Ltd., Seoul, South Korea). A concentration of $1 \mathrm{mg} / \mathrm{mL}$ of purified lyophilized PHA (Sigma-Aldrich Korea Ltd., Yongin, South Korea) in saline was made as a standard. Control was prepared using only saline and erythrocytes suspension. The hemagglutination titer (HT), defined as the reciprocal of the highest dilution exhibiting hemagglutination, is reckoned as one hemagglutination unit (HU). 
Specific activity is the number of HU per mg protein [11]. Experiments were conducted in triplets and mean value was taken.

\section{Anti-PHA serum production}

Preimmunization blood was drawn from the marginal ear vein of young New Zealand White rabbit weighing ca. $4.2 \mathrm{~kg}$ (Institut Pasteur Korea, Seongnam, Gyeonggi, South Korea) before they were immunized with $50 \mu \mathrm{g}$ purified PHA/kg body weight [12]. The lectin was emulsified in Freund's complete adjuvant, and the injection was made in the thicker part of the skin above the scapula. This subcutaneous administration was repeated on days 14,28 , and 42 with the antigen emulsified in Freund's incomplete adjuvant. A week after the last injection, blood was drawn from the ear vein and allowed to clot at room temperature before centrifugation at $3500 \mathrm{rpm}$ for $30 \mathrm{~min}$. The resulting serum was collected, precipitated using $40 \%$ ammonium sulfate and dialyzed against $0.01 \mathrm{M}$ Na-phosphate buffer $\mathrm{pH} 7.2$ before being used in the immunoassay. The antiserum was found to be monospecific to PHA as judged by double radial immunodiffusion and crossed immunoelectrophoresis using purified antigen as well as crude seed extract containing the antigen.

\section{Agar gel diffusion test}

The reaction of lectins suspended in the crude bean extract with rabbit anti-PHA antibodies was investigated using double immunodiffusion (Ouchterlony method) [13]. Microscope slides were precoated with $0.5 \%$ agar $\left(0.2 \mathrm{~mL} / \mathrm{cm}^{2}\right.$, Sigma-Aldrich Korea Ltd., Yongin, South Korea) and left on a horizontal surface overnight at room temperature until the agar was completely dry. The slides were then coated with $1 \%$ agar in PBS-azide solution. The central hole and the six peripheral holes were punched with a Pasteur pipette. A volume of $7 \mu \mathrm{L}(1 \mathrm{mg} / \mathrm{mL})$ of rabbit anti-PHA antibodies was added in the central hole, and the surrounding holes were filled with $7 \mu \mathrm{L}$ of crude bean extract $(100 \mathrm{mg} / \mathrm{mL})$. For the negative control, $7 \mu \mathrm{L}$ of normal rabbit serum $(1 \mathrm{mg} / \mathrm{mL})$ was placed in the central hole. The immunoprecipitin lines were evaluated after incubation for $48 \mathrm{~h}$ at room temperature in a humid chamber. The gel was stained in a solution of $0.025 \%$ Coomassie brilliant blue $\mathrm{R}$ in methanol:water:acetic acid (50:45:5 by volume) during $30 \mathrm{~min}$ and destained in a solution of water:acetic acids:methanol (87:8:5 by volume) overnight.

\section{Extraction of seed proteins}

The extraction of proteins from seed flour was done following the method of Itoh etal. [14] with slight modifications. Briefly, 100 g of kidney beans (P. vulgaris $\mathrm{L}$.) were soaked overnight in $1 \mathrm{~L}$ of distilled water at room temperature (ca. $25^{\circ} \mathrm{C}$ ), which will help in softening them. These soften seeds then crushed with tris- $\mathrm{NaCl}(50 \mathrm{mM}$ tris- $\mathrm{HCl}$ and $50 \mathrm{mM}$ $\mathrm{NaCl}$, at $\mathrm{pH} 7.6$ and $4^{\circ} \mathrm{C}$ ) in a mortar and pestle. The prepared mixture then centrifuged at $3500 \mathrm{rpm}$ at $4^{\circ} \mathrm{C}$ for $30 \mathrm{~min}$ and filtered through Whatman No. 1 filter paper. Finally, the liquid supernatant (i.e. referred to as the total crude extract) was precipitated using ammonium sulfate. The protein fractions were collected by centrifugation at $3500 \mathrm{rpm}$ for $30 \mathrm{~min}$, exhaustively dialyzed against tris- $\mathrm{NaCl}(\mathrm{pH} 7.6)$ in $10-\mathrm{kDa}$ molecular weight (MW) cutoff dialysis tubing and subjected to sodium dodecyl sulfate-polyacrylamide gel electrophoresis (SDS-PAGE). The samples were stored at $-20^{\circ} \mathrm{C}$ for further use.

\section{Protein determination}

Protein concentration was determined according to Bradford method [15] using bovine serum album (BSA) as standard. Readings at $280 \mathrm{~nm}$ were also used to determine protein content of the column eluates.

\section{SDS-PAGE}

SDS-PAGE was performed in a Mini-Protean II $7 \mathrm{~cm} \times 8 \mathrm{~cm} \times 0.75 \mathrm{~cm}$ slab cell (Bio-Rad Laboratories, Paris, France) using the Laemmli buffer system [16]. The samples (e.g. the standard proteins, purified PHA, and phaseolin, and total protein extract of the kidney beans) were denatured by a $15 \mathrm{~min}$ treatment at $100^{\circ} \mathrm{C}$ in a $0.0625 \mathrm{M}$ tris- $\mathrm{HCl}(\mathrm{pH}$ 6.8) buffer containing 10\% SDS, 10\% glycerol, 2\% $\beta$-mercaptoethanol, and
$0.001 \%$ bromophenol blue. The running gel contained $15 \mathrm{~mL} \mathrm{30 \%}$ acrylamide, $8.4 \mathrm{~mL} 1.5 \mathrm{M}$ tris- $\mathrm{HCl}$ buffer ( $\mathrm{pH} 8.8$ ), $0.3 \mathrm{~mL} \mathrm{10 \%} \mathrm{SDS}$ (i.e. SDS), $0.15 \mathrm{~mL}$ ammonium persulfate, $15 \mu \mathrm{L}$ TEMED (i.e. NNNNtetramethylethylenediamine), and $6.3 \mathrm{~mL}$ water. The stacking gel contained $2 \mathrm{~mL} 30 \%$ acrylamide, $1.5 \mathrm{M}$ tris- $\mathrm{HCl}$ buffer (pH 8.8), $0.1 \mathrm{~mL}$ $10 \%$ SDS, $0.1 \mathrm{~mL}$ ammonium persulfate, $5 \mu \mathrm{L}$ TEMED, and $5.3 \mathrm{~mL}$ water. The electrophoresis was carried out at $30 \mathrm{~mA}$ for $5 \mathrm{~h}$ with a tris-glycine ( $0.025 \mathrm{mM}$ tris, $0.192 \mathrm{M}$ glycine, $0.1 \% \mathrm{SDS}, \mathrm{pH}$ 8.3) electrode buffer. The gels were fixed in 50\% TCA (i.e. trichloroacetic acid), stained with a $0.1 \%$ Coomassie brilliant blue (G-250, Sigma-Aldrich Korea Ltd., Yongin, South Korea) solution, and then destained in a methanol/acetic acid/ water solution (40:7:53 v/v/v). Marker proteins were used, with the following MW: $\alpha$-lactalbumin (14.00 kDa), soybean trypsin inhibitor (21.50 kDa), carbonic anhydrase (31.00 kDa), ovalbumin (45.00 kDa), BSA (66.00 kDa), and phosphorylase (92.40 kDa) (Sigma-Aldrich Korea Ltd., Yongin, South Korea).

\section{RESULTS AND DISCUSSION}

\section{HA}

HA was performed to check the presence of lectins in the Korean cultivar beans. The crude extract from beans of $P$. vulgaris $\mathrm{L}$. contains effectively detectable levels of lectin activity as shown by the ability of this extract to agglutinate erythrocytes (Fig. 2). The specific activity was found to be $16 \mathrm{HU} / \mathrm{mg}$ and $77.10 \mathrm{HU} / \mathrm{mg}$, for the commercial lyophilized PHA and the extract, respectively, as displayed in Table 1.

\section{Agar gel diffusion}

The crude bean extract that was positive by hemagglutination testing was also positive by Ouchterlony testing. The reaction of PHAs suspended naturally in the bean extract, with rabbit anti-PHA antibodies by double immunodiffusion (Ouchterlony method) gave

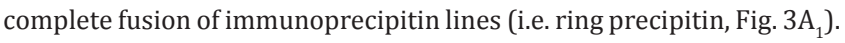
No precipitin lines were found in negative control (Fig. $3 \mathrm{~A}_{0}$ ). These results imply the immunobiochemical identity of PHA with rabbit PHA antibodies.
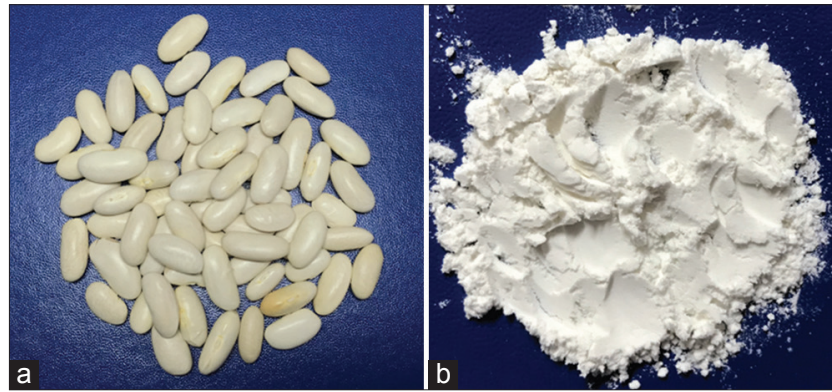

Fig. 1: Common bean (Phaseolus vulgaris L.) (a) and its fine powder (b)

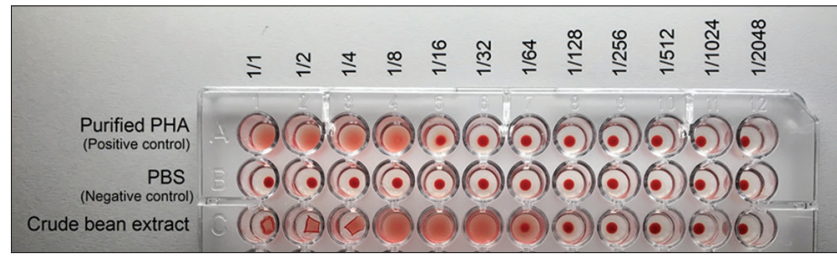

Fig. 2: Hemagglutination assay of crude common bean (Phaseolus vulgaris $\mathrm{L}$.) extract toward human erythrocytes type $A$. The two top rows contain PHA $(1 \mathrm{mg} / \mathrm{mL}$, Sigma-Aldrich Korea Ltd., Yongin, South Korea) as a positive control and PBS as a negative control. The bottom row contains the crude bean extract $(100 \mathrm{mg} / \mathrm{mL})$. The HT or the amount of $\mathrm{HU}$ was calculated according to the well with the highest dilution giving a complete hemagglutination. The assay was performed in triplicate in $\mathrm{U}$-bottomed microtiter plates and incubated for $1 \mathrm{~h}$ at $37^{\circ} \mathrm{C}$. 
Table 1: Hemagglutination activity of crude common bean (Phaseolus vulgaris L.) extract

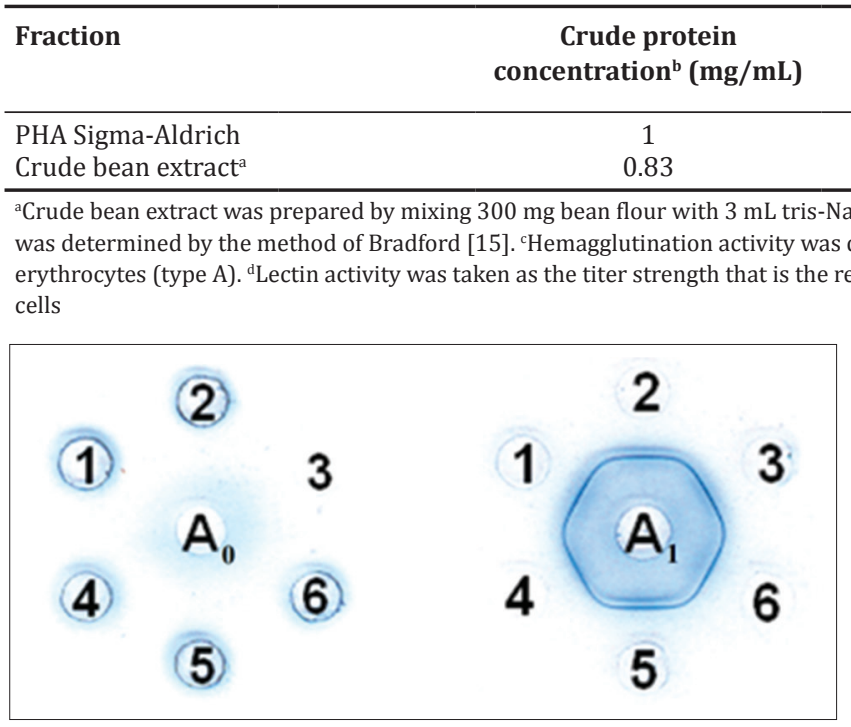

Fig. 3: Double immunodiffusion of the crude common bean (Phaseolus vulgaris L.) extract with rabbit PHA antibodies. $n$ (1 6): The crude extract was applied in wells in a circular distribution. $A_{0}$ : For negative control, normal rabbit serum $(7 \mu \mathrm{L}, 1 \mathrm{mg} / \mathrm{mL})$ was placed in the central hole. $A_{1}$ : Rabbit anti-PHA antibodies $(7 \mu \mathrm{L}, 1 \mathrm{mg} / \mathrm{mL})$ were added in the central hole as described in materials and methods section. Extract was obtained after homogenization of $300 \mathrm{mg}$ bean flour with $3 \mathrm{~mL}$ tris-NaCl buffer (pH 7.6), centrifugation, and supernatant dialysis. The incubation was carried out for $48 \mathrm{~h}$ in a moist chamber at room temperature

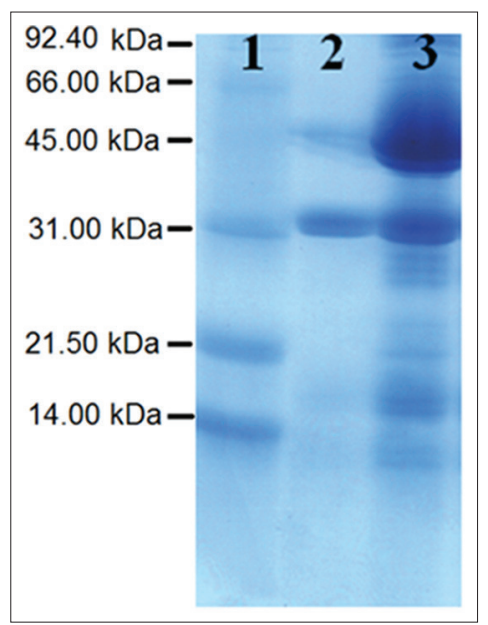

Fig. 4: Sodium dodecyl sulfate-polyacrylamide gel electrophoresis of the crude common bean (Phaseolus vulgaris L.) extract. Lane 1. MW standards. From top downward, phosphorylase ( $92.40 \mathrm{kDa})$, BSA (66.00 kDa), ovalbumin (45.00 kDa), carbonic anhydrase (31.00 kDa), soybean trypsin inhibitor ( $21.50 \mathrm{kDa})$, and $\alpha$-lactalbumin (14.00 kDa) (Sigma-Aldrich Korea Ltd., Yongin, South Korea). Lane 2. Phaseolin ( $45.00 \mathrm{kDa})$ and purified PHA ( $31.00 \mathrm{kDa}$ ) (Sigma-Aldrich Korea Ltd., Yongin, South Korea). Lane 3. Main protein fractions of Korean cultivar seeds consist of phaseolin subunits and phytohemagglutinin

\section{SDS-PAGE}

To obtain information on the complexity and abundance of lectin and lectin-related polypeptides in Korean bean cultivars, an electrophoretic analysis was performed. SDS-PAGE separates the proteins of the crude bean extract according to their electrophoretic mobility as a function of length of polypeptide chain or MW. As depicted in Fig. 4, the first column of the gel (Lane 1) represents the MW standards, and in the others, columns are displayed the MW subunits of purified PHA $(\sim 31.00 \mathrm{kDa})$ and phaseolin $(\sim 45.00 \mathrm{kDa})$ (Lane 2$)$ and those from the crude bean extract (Lane 3). The crude extract was found to contain a large number of bands, indicating the existence of different types of proteins.

Dry bean proteins are considered as storage and metabolic proteins, composed of globulins (40 60\%) and albumins (20 40\%). Globulins are highly recognized storage proteins and albumins have both storage and metabolic proteins. Because of diversity in the name of storage proteins; therefore, there is no clear nomenclature for dry beans. According to the ultracentrifugation sedimentation coefficient (S), dry beans contain both types of storage proteins, namely 7S (vicilin-like) and $11 \mathrm{~S}$ (legumin-like). Depending on the bean variety or cultivar, the relative fraction of these types of proteins varies substantially. The 7S globulin found in Phaseolus beans also is referred as glycoprotein II, globulin 1, euphaseolin, globulin, and phaseolin [17].

The three major types of $7 \mathrm{~S}$ proteins that have been identified in this study are as follows: (a) Phaseolin, (b) lectin (also called glycoprotein II, phytoagglutinins or PHAs, and protein II), and (c) arcelin (Fig. 4):

a. Phaseolin is the major globulin component of kidney beans $P$. vulgaris $\mathrm{L}$. It consists of a group of subunit polypeptides with MWs $43.00 \sim 53.00 \mathrm{kDa}(\alpha-(53.00 \mathrm{kDa}), \beta-(47.00 \mathrm{kDa})$, and $\gamma-$ (43.00 kDa)) [18].

b. Lectins (PHAs) occur in both albumin and globulin fractions. They constitute about $6 \sim 12 \%$ of the total protein content [17]. The lectins of Korean cultivated kidney beans are found to have subunits of MW $30.00 \sim 32.00 \mathrm{kDa}$. These bands were also reported by Ren et al. for red kidney beans (P. vulgaris L.) [19].

c. Arcelin occurs in lines that contain phaseolin as well as lectin. Because it is present in equal or greater levels than phaseolin in certain lines, it is one of the major storage proteins in P. vulgaris beans. Depending on the variety, the MW of the arcelin subunit polypeptide ranges from 35.00 to $42.00 \mathrm{kDa}$. The biochemical properties of arcelin were found to be similar to lectin (including agglutinating activity). The major sugar constituents of $7 \mathrm{~S}$ globulin protein are D-mannose and D-glucosamine [17].

The 11S-type proteins typically are non-glycosylated proteins with estimated MW in the range of $300 \sim 400 \mathrm{kDa}$. There are six subunits of $11 \mathrm{~S}$ proteins and each consists of one acidic (MW $40.00 \mathrm{kDa}$ ) and one basic polypeptide (MW $20.00 \mathrm{kDa}$ ) which are linked through disulfide bond (s) [17]. In general, 11S proteins are present in minor amounts in P. vulgaris. They appeared as major bands around $40.00 \mathrm{kDa}$ and minor bands around $20.00 \mathrm{kDa}$ in the SDS-PAGE electrogram pattern (Fig. 4).

\section{CONCLUSION}

The results presented here provide evidence that the Korean cultivar of the common bean (P. vulgaris L.) contains a lectin-related 31-kDa protein, which agglutinates blood type A cells and precipitates rabbit anti-PHA antibodies in agar gel diffusion slides. Further, in vivo studies are warranted with the raw beans to confirm its contribution to various symptoms of foodborne illness. 


\section{ACKNOWLEDGMENTS}

This work was supported by "Korea-Tunisia joint research Programme" grant funded by the Korea government (Ministry of Science, ICT and Future Planning) in 2016 (NRF-2016K1A3A1A09919130).

\section{CONFLICTS OF INTEREST}

The authors declare that they have no conflicts of interest.

\section{REFERENCES}

1. Hayat I, Ahmad A, Masud T, Ahmed A, Bashir S. Nutritional and health perspectives of beans (Phaseolus vulgaris L.): An overview. Crit Rev Food Sci Nutr 2014;54:580-92.

2. Muzquiz M, Varela A, Burbano C, Cuadrado C, Guillamón E, Pedrosa MM. Bioactive compounds in legumes: Pronutritive and antinutritive actions Implications for nutrition and health. Phytochem Rev 2012;11:227-44

3. Nciri N, Cho N, El Mhamdi F, Ben Ismail H, Ben Mansour A, Sassi FH, et al. Toxicity assessment of common beans (Phaseolus vulgaris L.) widely consumed by Tunisian population. J Med Food 2015;18:1049-64.

4. Shang R, Wu H, Guo R, Liu Q, Pan L, Li J, et al. The diversity of four anti-nutritional in common bean. Horticult Plant J 2016;2:97-104.

5. Greer F, Brewer AC, Pusztai A. Effect of kidney bean (Phaseolus vulgaris) toxin on tissue weight and composition and some metabolic functions of rats. Br J Nutr 1985;54:95-103

6. Bardocz S, Grant G, Pusztai A. The effect of phytohaemagglutinin at different dietary concentrations on the growth, body composition and plasma insulin of the rat. Br J Nutr 1996;76:613-26.

7. Nciri N, Cho N, Bergaoui N, El Mhamdi F, Ben Ammar A, Trabelsi N, et al. Effect of white kidney beans (Phaseolus vulgaris L. Var. Beldia) on small intestine morphology and function in wistar rats. J Med Food 2015;18:1387-99.

8. Banwell JG, Abramowsky CR, Weber F, Howard R, Boldt DH.
Phytohemagglutinin-induced diarrheal disease. Dig Dis Sci 1984;29:921-9.

9. Pusztai A, Palmer R. Nutritional evaluation of kidney beans (Phaseolus vulgaris): The toxic principle. J Sci Food Agr 1977;28:620-3.

10. Nciri N, Cho N, El Mhamdi F, Ben Mansour A, Haj Sassi F, Ben Aissa-Fennira $\mathrm{F}$, et al. Identification and characterization of phytohemagglutinins from white kidney beans (Phaseolus vulgaris L. var. Beldia) in the rat small intestine. J Med Food 2016;19:85-97.

11. Wang H, Gao J, Ng TB. A new lectin with highly potent antihepatoma and antisarcoma activities from the oyster mushroom Pleurotus ostreatus. Biochem Biophys Res Commun 2000;275:810-6.

12. Harboe N, Ingild A. 23. Immunization, isolation of immunoglobulins, estimation of antibody titre. Immunology 1973;2:161-4

13. Ouchterlony O. Antigen-antibody reactions in gels. Acta Pathol Microbiol Scand 1949;26:507-15.

14. Itoh M, Kondo K, Komada H, Izutsu K, Shimabayashi Y, Takahashi T. Purification and characterization of a lectin from Phaseolus vulgaris seed. Agr Biol Chem 1980;44:125-33.

15. Bradford MM. A rapid and sensitive method for the quantification of microgram quantities of protein utilizing the principle of protein-dye binding. Anal Biochem 1976;72:248-54.

16. Laemmli UK. Cleavage of structural proteins during the assembly of the head of bacteriophage T4. Nature 1970;227:680-5.

17. Michaels TE. The legumes and pseudocereals-grain legumes and their dietary impact: Overview. In: Wrigley C, Corke H, Seetharaman K, Faubion J, editors. Encyclopedia of Food Grains-The World of Food Grains, $2^{\text {nd }}$ ed. Oxford, UK: Elsevier Science and Technology; 2016. P. 265-73.

18. Yin SW, Tang CH, Wen QB, Yang XQ, Li L. Functional properties and in vitro trypsin digestibility of red kidney bean (Phaseolus vulgaris L.) protein isolate: Effect of high-pressure treatment. Food Chem 2008;110:938-45.

19. Ren J, Shi J, Kakuda Y, Kim D, Xue SJ, Zhao M, et al. Phytohemagglutinin isolectins extracted and purified from red kidney beans and its cytotoxicity on human H9 lymphoma cell line. Sep Purif Technol 2008;63:122-8. 